\title{
PERAMALAN PENJUALAN AIR MINUM ISI ULANG 19 LITER PADA USAHA DEPOT TIRTA ASRI UNTUK MENINGKATKAN VOLUME PENJUALAN TAHUN 2016 DI DAERAH TAJUR HALANG BOGOR DENGAN METODE FORECASTING
}

\author{
Rizka Fernanda Rumai Damayanti \\ Alumni Program Manajemen S1 \\ Sekolah Tinggi Ilmu Ekonomi Bisnis Indonesia, Jakarta \\ Dan \\ Alaidin Rapani \\ Dosen STIE Bisnis Indonesia, Jakarta
}

\begin{abstract}
The purpose of this study to determine the development of business by forecasting sales at drinking water refill depots Tirta Asri Tajur Halang Bogor. The method used in this research is the approach of six methods of forecasting. This study shows forecasting results for Exponential Smoothing with $M A D=186,9520$ and $M S E=44017,0091$, weighted moving average with $M A D=$ 192 and $M S E=52418,2866$, moving average with $M A D=182,8886$ and $M S E=50966,1063$, linear regression with $M A D=134,2571$ and $M S E=22649,1809$, naive method with $M A D=246,4$ and $M S E$ $=73564,8$, exponential smoothing wiyh trend with $M A D=177,2625$ and $M S E=46714,1544$. Thus the most appropriate linear regression method is used to forecasting sales, because the error results are smaller than th other five methods.
\end{abstract}

Keywords: Forecasting, Sales, QMFor Windows.

\begin{abstract}
Abstrak: Tujuan penelitian ini untuk mengetahui perkembangan usaha dengan melakukan peramalan penjualan pada depot air minum isi ulang Tirta Asri di Tajur Halang Bogor. Metode yang digunakan dalam penelitian ini adalah pendekatan enam metode forecasting. Penelitian ini menunjukkan hasil peramalan untuk exponential smoothing dengan $\mathrm{MAD}=186,9520$ dan $\mathrm{MSE}=$ 44017,0091, weighted moving average dengan $\mathrm{MAD}=192$ dan $\mathrm{MSE}=52418,2866$, moving average dengan $\mathrm{MAD}=182,8886$ dan $\mathrm{MSE}=50966,1063$, linear regression dengan $\mathrm{MAD}=134,2571$ dan $\mathrm{MSE}=22649,1809$, naive method dengan $\mathrm{MAD}=246,4$ dan $\mathrm{MSE}=73564,8$, exponential smoothing with trend dengan MAD $=177,2625$ dan MSE $=46714,1544$. Dengan demikian metode linear regression yang paling tepat digunakan untuk melakukan peramalan penjualan, karena hasil kesalahan lebih kecil dibandingkan dengan lima metode lainnya.
\end{abstract}

Kata kunci: Peramalan, Penjualan, QMFor Windows. 


\section{Pendahuluan}

Air merupakan zat penting yang sangat dibutuhkan makhluk hidup, terutama manusia. Air memegang peranan penting dalam proses metabolisme tubuh, dimana air merupakan pelarut dan hampir semua jenis zat dapat larut dalam air. Air dalam tubuh manusia berkisar antara 50\%-70\% dari seluruh berat badan. Manusia membutuhkan air untuk melakukan kegiatan sehari-hari termasuk mencuci, mandi, minum dan lain-lain. Seiring perkembangan dunia usaha yang banyak bermunculan dan tumbuh semakin cepat, hal ini mengakibatkan semakin meningkatnya suatu persaingan usaha. Menghadapi persaingan tersebut, perusahaan atau pimpinan dituntut untuk mampu meningkatkan kinerja usaha yang baik, sehingga perusahaan akan dapat menjamin kelangsungan hidupnya. Perusahaan harus mengutamakan kepuasan bagi para pelanggannya. Pelanggan akan merasa puas apabila produk atau jasa yang ditawarkan perusahaan sesuai dengan yang diinginkan pelanggan.

Kepuasan pelanggan merupakan salah satu penentu keberhasilan perusahaan. Kelangsungan hidup sebuah perusahaan sangat tergantung pada kepuasan pelanggan. Sebuah perusahaan yang mampu memuaskan pelanggannya, tetapi tidak mampu menghasilkan laba, maka perusahaan itu tidak akan berkembang. Menghadapi persaingan yang makin ketat maka dibutuhkan strategi bisnis yang tepat dan berkualitas untuk menghadapi persaingan tersebut. Dengan adanya strategi bisnis yang tepat diharapkan dapat memberikan pengaruh positif bagi perusahaan terutama dari segi penjualan dan pendapatan serta perkembangan perusahaan. Depot air minum isi ulang Tirta Asri adalah usaha industri yang melakukan proses pengolahan air baku menjadi air minum dan menjual langsung kepada konsumen. Air baku yang di gunakan depot air minum harus memenuhi standar mutu dan persyaratan kualitas air minum sebagai mana di atur dalam peraturan menteri kesehatan. Saat ini penggunaan AMIU semakin populer digunakan oleh masyarakat, alasan pertama karena tingginya tingkat pencemaran limbah pada air tanah sebagai sumber air. Alasan kedua adalah PDAM tidak mampu melayani kebutuhan seluruh masyarakat akan air bersih dan air minum. Alasan ketiga adalah sulitnya menemukan sumber air bersih saat musim kemarau terutama di daerah-daerah yang kekurangan air. Alasan keempat karena harga AMIU yang di tawarkan lebih murah sepertiga dari produk air minum dalam kemasan yang bermerek. Alasan kelima adalah pengaruh gaya hidup masyarakat yang ingin mendapatkan sesuatu dengan cara yang praktis.

Tingginya permintaan terhadap AMIU oleh banyak rumah tangga menyebabkan banyaknya kegiatan penjualan air minum isi ulang bermunculan dan semakin mudah di temukan. Banyaknya depot AMIU juga mempengaruhi daya saing penjualan meskipun harga yang di tawarkan lebih murah, ternyata tidak semua produk AMIU terjamin keadaan produknya, terutama dari ancaman kontaminasi biologi. Air minum yang aman haruslah memenuhi standar yang telah ditetapkan mulai dari aspek fisik, kimia, mikrobiologi dan radio aktif sesuai dengan permenkes RI Nomor 492/MENKES/PER/IV/2010 (Prihatini, 2012).

\section{Tinjauan Teori}

\subsection{Manajemen Keuangan}

Manajemen keuangan merupakan fungsi untuk mendapatkan sumber keuangan dari berbagai pihak dengan biaya yang seefisien mungkin, serta fungsi untuk mengalokasikan uang yang sudah diperoleh tersebut secara tepat guna dalam rangka mencapai tujuan perusahaan yang sudah ditetapkan (Suparyanto dan Bari, 2014). Manajemen keuangan perusahaan merupakan penggabungan dari ilmu dan seni yang membahas, mengkaji dan menganalisis tentang bagaimana seorang manajer keuangan dengan mempergunakan seluruh sumber daya perusahaan untuk mencari dana, mengelola dana, dan membagi dana dengan tujuan mampu memberikan profit bagi para pemegang saham dan usaha bagi perusahaan. Bidang manajemen keuangan memiliki tiga ruang lingkup yang harus dilihat oleh seorang manajer keuangan yaitu: 
1. Bagaimana mencari dana

2. Bagaimana mengelola dana

3. Bagaimana membagi dana

Ilmu manajemen keuangan berfungsi sebagai pedoman bagi manajer perusahaan dalam setiap pengambilan keputusan yang dilakukan. Artinya seorang manajer keuangan boleh melakukan suatu keputusan dan kreatifitas berpikir, akan tetapi semua itu tetap tidak mengesampingkan kaidah-kaidah yang berlaku dalam ilmu manajemen keuangan. Seperti mematuhi aturan-aturan yang terkandung dalam SAK (Standar Akuntansi keuangan), undang-undang dan peraturan tentang pengelolaan keuangan perusahaan. Tujuan dari manajemen keuangan yaitu:

1. Memaksimumkan nilai perusahaan.

2. Menjaga stabilitas finansial dalam keadaan yang selalu terkendali.

3. Memperkecil risiko perusahaan dimasa sekarang dan yang akan datang.

Memaksimumkan nilai perusahaan adalah bagaimana pihak manajemen perusahaan mampu memberikan nilai yang maksimum pada saat perusahaan tersebut masuk ke pasar (Fahmi, 2014).

\subsubsection{Pemasaran}

Menurut Assauri dalam Boneta (2013) pemasaran adalah kegiatan manusia yang diarahkan untuk memenuhi dan memuaskan kebutuhan dan keinginan melalui proses pertukaran. Kegiatan pemasaran bukan aktifitas yang berdiri sendiri, melainkan terkait dengan fungsi-fungsi lainya di dalam perusahaan (Zulkarnain, 2012). Adapun fungsi-fungsi pemasaran sekurangnya terdiri dari:

1. Pembelian (buying).

2. Penjualan (selling).

3. Penggudangan (storage).

4. Transportasi(transportation).

5. Pembiayaan(financing).

6. Pengambilan resiko (risk taking).

7. Penyortiran (sorting).

8. Menentukan tingkatan mutu (grading).

Strategi pemasaran merangkum cara-cara dimana bauran pemasaran disyukuri untuk menarik dan memuaskan pasar sasaran dan sekaligus mewujudkan tujuan perusahaan. Bagi perusahaan besar yang memiliki banyak $S B U$ (Strategic Businness Unity) perencanaan strategis operasionalnya akan berbeda dari satu SBU lainnya. Harus diusahakan agar strategi pemasarannya sejelas mungkin. Terdapat 3 kelompok strategi yang akan dijelaskan, yakni:

1. Strategi inti

2. Strategi dasar

3. Posisi strategis,

\subsubsection{Penjualan}

Marwan dalam Sopiah dan Sangadji (2016) Penjualan adalah suatu usaha yang terpadu untuk mengembangkan rencana-rencana strategis yang diarahkan pada usaha memenuhi kebutuhan dan keinginan pembeli guna mendapatkan penjualan yang menghasilkan laba. Menurut Baduara dalam Sopiah dan Sangadji (2016) penjualan merupakan suatu kemampuan yang menunjukkan loyalitas penjual, kualitas produk yang dijual, peranan penjual dalam pendekatan kepada orang lain yang dapat memberikan pelayanan, pertolongan atau bantuan kerjasama. Pentingnya strategi dalam penjualan. Salah satu strategi dalam penjualan yang banyak dikenal yakni (Sopiah dan Sangadji, 2016): 
1. Segmentasi

2. Targeting

3. Positioning

Proses atau siklus menjual berlaku umum, artinya hubungan antara penjual dengan pembeli, apapun produk yang akan memperjual belikan. Berikut siklus atau proses menjual.

Gambar 2.1

Siklus Menjual Produk

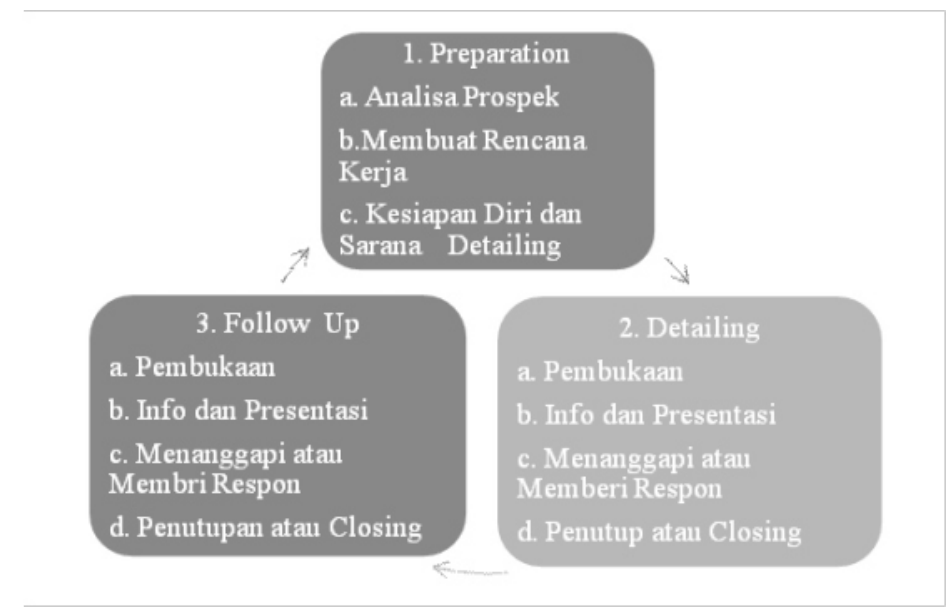

Sumber: Sopiah dan Sangadji, 2016.

1. Preparation (persiapan) persiapan merupakan tahapan prakunjungan penjualan dengan persiapan.

2. Detailing (wawancara menjual) untuk mencari informasi yang dibutuhkan, yaitu perlu komunikasi dalam memperkenalkan diri untuk mendapatkan perhatian dan minat klien terhadap produk yang ditawarkan.

3. Follow Up (tindak lanjut setelah kunjungan) adapun tindak lanjut setelah kunjungan adalah memenuhi permintaan, evaluasi hasil kunjungan, produk dan fokus pembicaraan selanjutnya.

Standard Operating Procedure (SOP) administrasi penjualan adalah pedoman yang menjadi acuan cara pelaksanaan administrasi penjualan. Standar Operating Procedure (SOP) administrasi penjualan dalam kode etik APLI

\subsubsection{Peramalan}

Peramalan adalah penggunaan data masa lalu dari sebuah variabel atau kumpulan variabel untuk mengestimasi nilainya dimasa yang akan datang (Stepvhanie, 2012). Gasperz dalam Wibowo (2010) aktivitas peramalan merupakan suatu fungsi bisnis yang berusaha memperkirakan penjualan dan penggunaan produk sehingga produk-produk itu dapat dibuat dalam kuantitas yang tepat. Peramalan (Forecasting) adalah seni dan ilmu untuk memperkirakan kejadian dimasa depan. Hal ini dapat dilakukan dengan melibatkan pengambilan data masa lalu dan menempatkannya kemasa yang akan datang dengan suatu bentuk model matematis (Heizer dan Render, 2006). Peramalan memiliki peranan yang penting dalam sebuah perusahaan, dikarenakan peramalan merupakan dasar dari sebuah perencanaan produksi yang juga berkaitan dengan inventory. Peramalan menjadi penting sebab situasi dan kondisi yang berkaitan dengan ekonomi dan kegiatan usaha dihadapkan pada: 
Gambar 2.2

Sifat-sifat Peramalan

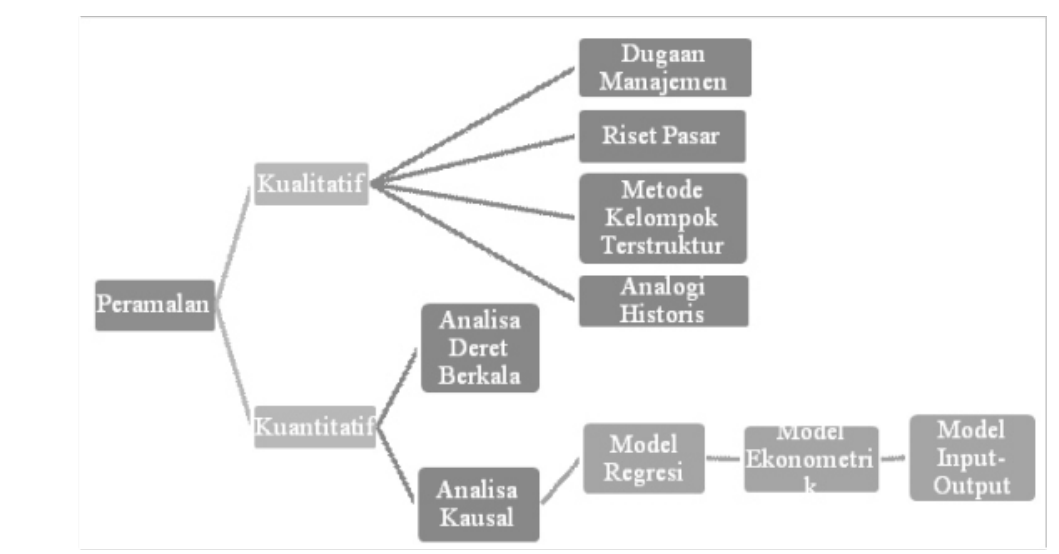

Sumber: Stepvhanie, 2012.

1. Meningkatnya kompleksitas organisasi.

2. Meningkatnya ukuran-ukuran keberhasilan organisasi.

3. Perubahan lingkungan yang sangat cepat.

\subsubsection{Air Minum}

Air minum sangat penting untuk kebutuhan makhluk hidup, oleh karena itu pasokan air harus memadai, aman, dan mudah di akses. Peningkatan akses air minum yang aman dapat bermanfaat bagi kesehatan. Oleh karena itu setiap upaya perlu di lakukan untuk mendapatkan air minum yang aman. Definisi air minum adalah air yang telah memenuhi persyaratan kesehatan, melalui proses pengolahan ataupun tidak melalui proses pengolahan tetapi dapat langsung diminum oleh masyarakat (permenkes RI Nomor 492/MENKES/PER/IV/2010). Sedangkan berdasarkan keputusan menteri perindustrian dan perdagangan republik Indonesia nomor 651/MPP/kep/10/2004 tentang persyaratan teknis depot air minum dan perdagangannya, yang di maksud dengan air minum adalah sumber air baku yang telah di proses terlebih dahulu dan aman untuk di minum oleh masyarakat. Berdasarkan peraturan menteri kesehatan no. 736 tahun 2010, sumber air minum dapat diperoleh dari air kemasan, air minum yang didistribusikan melalui pipa untuk keperluan rumah tangga serta air yang didistribusikan melalui tanki air. Jenis dari air minum tersebut harus memenuhi syarat kesehatan air minum. Sumber air minum layak atau tidak untuk dikonsumsi. Sumber air utama bagi penyediaan air minum dibedakan menjadi dua yaitu, air tanah dan air permukaan. Peran air sangatlah penting bagi kehidupan.

Air sangat dibutuhkan sebagai media untuk merubah berbagai proses kimia yang terjadi di dalam tubuh seperti pemecahan gula atau lemak menjadi bentuk yang lebih sederhana. Air juga berfungsi sebagai pelumas dan mencegah terjadinya pergeseran antar sendi ketika gerakan sendi terjadi. Temperatur tubuh juga diatur melalui penguapan air kulit dan paru-paru (Prihatini, 2012). Dimana temperaturnya normal yaitu air yang baik harus memiliki temperatur sama dengan temperatur udara (20-26 derajat celcius). Air yang secara mencolok mempuyai temperatur di atas atau di bawah temperatur udara, berarti mengandung zat-zat tertentu (misalnya fenol yang terlarut dalam air cukup banyak) atau sedang terjadi proses tertentu (proses dekomposisi bahan organik oleh mikroorganisme yang menghasilkan energi) yang mengeluarkan atau menyerap energi dalam air. Rasanya tawar yaitu air bisa dirasakan oleh lidah. Air yang terasa asam, manis, pahit, atau asin menunjukkan bahwa kualitas air tersebut tidak baik. Rasa asin disebabkan oleh adanya garam tertentu yang larut dalam air, sedangkan rasa asam diakibatkan adanya asam organik maupun asam anorganik. 
Tidak berbau yaitu air yang baik memiliki ciri tidak berbau bila dicium dari jauh maupun dari dekat. Air yang berbau busuk mengandung bahan organik yang sedang mengalami dekomposisi (penguraian) oleh mikro organisme air. Jernih atau tidak berbau yaitu air yang keruh disebabkan oleh adanya butiran-butiran koloid dari bahan tanah liat, semakin banyak kandungan koloid maka air makin keruh. Derajat kekeruhan dinyatakan dengan satuan unit. Tidak mengandung zat padatan yaitu air minum yang baik tidak boleh mengandung zat padatan, walaupun jernih, air yang mengandung padatan yang terapung tidak baik digunakan sebagai air minum. Apabila air di didihkan zat padat tersebut dapat larut sehingga menurunkan kualitas air minum (Prihatini, 2012).

\subsection{Kerangka Pikir}

Kerangka pemikiran adalah narasi atau uraian atau pernyataan (proposisi) tentang kerangka konsep pemecahan masalah yang telah di identifikasi atau dirumuskan. Kerangka pemikiran dalam penelitian ini yaitu suatu perusahaan pasti mempunyai tujuan salah satunya yaitu meningkatkan volume penjualan.

Gambar 2.3

\section{Bagan Kerangka Pikir}

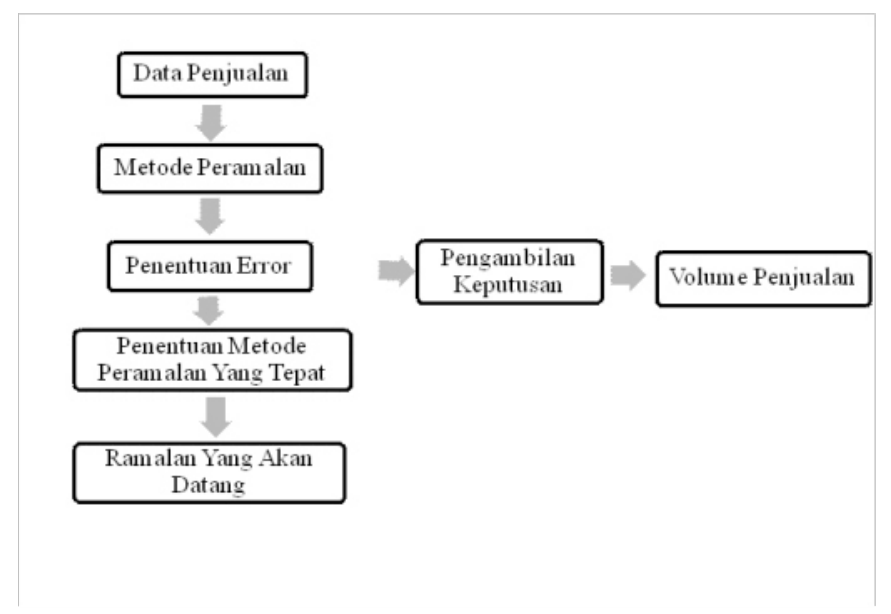

Sumber: Penulis, 2017

Setiap perusahaan pasti mengalami naik turun dalam menjalankan usahanya, begitu juga dengan penjualan air minum isi ulang Tirta Asri, sehingga perusahaan perlu membuat suatu peramalan penjualan. Dimana untuk membuat peramalan tersebut membutuhkan suatu data historis pada periode-periode sebelumnya. Data sebelumnya digunakan untuk meramalkan penjualan periode yang akan datang. Dalam menghitung data tersebut digunakan enam metode yaitu, Linear Regression, Exponential Smoothing With Trend, Exponential Smoothing, Weighted Moving Average, Moving Average, Naive Method. Dari hasil peramalan tersebut dicari tingkat kesalahan pada masingmasing metode peramalan. Menghitung kesalahan peramalan tersebut menggunakan MAD (Mean Absolute Error) dan MSE (Mean Square Error). Selanjutnya untuk mengetahui metode yang paling tepat yaitu dicari tingkat kesalahan (error) yang lebih mendekati nol pada masing-masing metode peramalan. Dari hasil peramalan tersebut dapat diketahui jumlah penjualan air minum isi ulang pada bulan Mei. Dengan adanya hasil peramalan tersebut, dapat memberikan kemudahan dalam mengetahui jumlah penjualan air minum isi ulang, hal tersebut akan dijadikan sebagai dasar dalam perencanaan produksi oleh pemilik usaha depot air minum isi ulang dalam memproduksi produk pada bulan Mei. Selanjutnya pemilik depot dapat mengambil keputusan setelah mengetahui data peramalan dan perencanaan tersebut untuk meningkatkan volume penjualan. 


\section{Metodologi Penelitian}

Menurut Sugiyono (2010:20) "Penelitian deskriptif yaitu metode penelitian yang digunakan untuk menganalisis suatu data statistik secara deskriptif." Sedangkan menurut Sujarweni (2014:11) "Penelitian desktiptif adalah jenis penelitian yang memberikan gambaran atau uraian atas suatu keadaan sejelas mungkin tanpa ada perlakuan terhadap objek yang diteliti."

\subsection{Jenis Dan Deskripsi Data}

Menurut Sujarweni (2014:73) "Data adalah kenyataan yang menggambarkan suatu kejadiankejadian dan kesatuan nyata. Kejadian merupakan sesuatu yang terjadi pada saat tertentu. Data bisa berarti deskripsi dari sesuatu dan kejadian yang sedang dihadapi. " Dalam penelitian ini digunakan data primer dan data sekunder:

1. Data primer

Menurut Sujarweni (2014:73) "Data primer merupakan data yang diperoleh secara langsung ditempat penelitian yang menjadi obyek penelitian." Data primer juga dapat disebut sebagai data yang diperoleh langsung dari responden melalui kuesioner atau wawancara dalam pengumpulan data, Untuk memperoleh data primer, peneliti melakukan observasi dan wawancara secara langsung dengan nara sumber (pimpinan usaha depot tirta asri) untuk mendapatkan data yaitu data penjualan air minum isi ulang tahun 2016 dan data mengenai profil perusahaan.

2. Data sekunder

Menurut Sujarweni (2014:74) "Data sekunder adalah data yang didapat dari catatan, buku, majalah berupa laporan keuangan publikasi perusahaan, laporan pemerintah, artikel, buku-buku sebagai teori, majalah dan sebagainya." Data yang diperoleh dari data sekunder tidak perlu diolah lagi. Data sekunder diperoleh secara tidak langsung dari tempat penelitian. Untuk mendapatkan data sekunder ini, peneliti membaca dan memahami buku-buku, jurnal yang berhubungan dengan peramalan (forecasting) dan penggunaan program QMfor Windows.

\subsection{Teknik Pengolahan Data}

Menurut Sujarweni (2014:103) "Analisis data diartikan sebagai upaya data yang sudah tersedia kemudian diolah dengan statistik dan dapat digunakan untuk menjawab rumusan masalah dalam penelitian." Dengan demikian, teknik analisis data dapat diartikan sebagai cara melaksanakan. Metode analisis yang digunakan dalam penelitian ini adalah analisis forecasting. Analisa forecasting Dalam analisa forecasting dilakukan dengan perhitungan secara manual dan menggunakan program QMfor Windows.

\subsection{Teknik Analisis Data}

\subsubsection{Perhitungan Manual}

Metode forecasting yang digunakan dalam penelitian ini terdiri dari enam metode, diantaranya adalah:

1. Metode regresi linier (linear regression)

2. Metode penghalusan eksponensial dengan tren (exponential smoothing with trend)

3. Metode penghalusan eksponensial (exponential smoothing)

4. Metode rata-rata tertimbang (weighted moving average)

5. Metode rata-rata bergerak (moving average)

6. Metode Naif (naive method)

\subsubsection{Menggunakan $Q M$ for Windows}

Program $Q M$ for Windows yang akan digunakan dalam penelitian ini adalah $Q M$ versi 2.2. Pada 
program ini peneliti akan lebih mudah untuk mendapatkan hasil peramalan yang diinginkan, dengan cara memasukkan data-data yang akan diteliti kemudian disesuaikan dengan metode yang akan digunakan. Seperti pada perhitungan manual, maka untuk mendapatkan hasil yang sama sebagai pembanding, metode yang digunakan untuk perhitungan menggunakan $Q M$ for Windows adalah: Linear regression, Exponential smoothing with trend, Exponential smoothing, Weighted moving average, Moving average dan Naive method

\section{Analisis dan Pembahasan}

Dari hasil pengamatan yang telah dilakukan terhadap penjualan air minum isi ulang pada depot Tirta Asri, maka memperoleh data penjualan air minum isi ulang periode November 2015 sampai April 2016 sebagai berikut:

Tabel 4.1

Penjualan Air Minum Isi Ulang Depot Tirta Asri

\begin{tabular}{|c|c|c|}
\hline Periode & Bulan & Jumlah Pejualan \\
\hline \multirow{2}{*}{2015} & November & 2.182 \\
\cline { 2 - 3 } & Desember & 1.861 \\
\hline \multirow{2}{*}{2016} & Januari & 2.004 \\
\cline { 2 - 3 } & Februari & 1.922 \\
\cline { 2 - 3 } & Maret & 2.299 \\
\cline { 2 - 3 } & April & 1.990 \\
\hline \multicolumn{2}{|c|}{ Jumlah } & 12.258 \\
\hline
\end{tabular}

Sumber: Depot AMIU Tirta Asri, 2017.

\subsection{Analisis}

Perhitungan manual:

\section{Exponential Smoothing}

Dalam peramalan ini peneliti menggunakan konstanta $\alpha=0,3$ (konstanta yang diambil merupakan angka antara $0-1)$.

\section{Tabel 4.2}

Hasil Penyelesaian Manual Dengan Metode Exponential Smoothing

\begin{tabular}{|l|c|c|l|l|}
\hline \multicolumn{1}{|c|}{ Bulan } & Periode & $\begin{array}{c}\text { Penjualan } \\
\text { (At) }\end{array}$ & \multicolumn{1}{|c|}{ Ft } & At - Ft \\
\hline November & 1 & 2182 & - & - \\
\hline Desember & 2 & 1861 & $2182+0,3(2182-2182)=2182$ & 321 \\
\hline Januari & 3 & 2004 & $2182+0,3(1861-2182)=2085,7$ & 81,7 \\
\hline Februari & 4 & 1922 & $\begin{array}{l}2085,7+0,3(2004-2085,7)= \\
2061,19\end{array}$ & 139,19 \\
\hline Maret & 5 & 2299 & $\begin{array}{l}2061,19+0,3(1922-2061,19)= \\
2019,433\end{array}$ & $\begin{array}{l}279,56 \\
7\end{array}$ \\
\hline April & 6 & 1990 & $\begin{array}{l}2019,433+0,3(2299-2019,433)= \\
2103,3031\end{array}$ & $\begin{array}{l}113,30 \\
31\end{array}$ \\
\hline Mei & 7 & - & $\begin{array}{l}2103,3031+0,3(1990- \\
2103,3031)=2069,3122\end{array}$ & - \\
\hline Jumlah & & & 934,76 \\
\hline
\end{tabular}

Sumber: Depot AMIU Tirta Asri, 2017.

Menghitung kesalahan atau error dengan menggunakan metode MAD (mean absolute deviation) dan MSE (mean squared error). 


$$
\begin{aligned}
& \text { MAD }=\frac{\Sigma \mid \text { Aktual }- \text { Peramalan } \mid}{\mathrm{n}} \\
& =\frac{321+81,7+139,19+279,567+113,3031}{5} \\
& =\frac{934,7601}{5}=186,9520 \\
& \mathrm{MSE}=\frac{\Sigma(\text { Kesalahan Peramalan })^{2}}{\mathrm{n}} \\
& \mathrm{MSE}=\frac{321^{2}+81,7^{2}+139,19^{2}+279,567^{2}+113,3031^{2}}{5} \\
& =\frac{103041+6674,89+19373,8561+78157,7074+12837,5924}{5} \\
& =\frac{220085,0459}{5}=44017,0091
\end{aligned}
$$

\section{Weighted Moving Average}

Dalam peramalan ini peneliti menggunakan bobot sebesar 0,$2 ; 0,3$ dan 0,5 (bobot pada tiga bulanan terakhir).

Tabel 4.3

Hasil Penyelesaian Manual Dengan Metode Weight Moving Average

\begin{tabular}{|l|l|l|l|l|}
\hline \multicolumn{1}{|c|}{ Bulan } & Periode & $\begin{array}{c}\text { Penjualan } \\
\text { (Yt) }\end{array}$ & \multicolumn{1}{|c|}{ Ft } & Yt - Ft \\
\hline November & 1 & 2.182 & - & - \\
\hline Desember & 2 & 1.861 & - & - \\
\hline Januari & 3 & 2.004 & - & - \\
\hline Februari & 4 & 1.922 & $\begin{array}{l}0,2(2182)+0,3(1861)+0,5(2004)= \\
1996,7\end{array}$ & 74,7 \\
\hline Maret & 5 & 2.299 & $\begin{array}{l}0,2(1861)+0,3(2004)+0,5(1922)= \\
1934,4\end{array}$ & 364,6 \\
\hline April & 6 & 1.990 & $\begin{array}{l}0,2(2004)+0,3(1922)+0,5(2299)= \\
2126,9\end{array}$ & 136,9 \\
\hline Mei & 7 & - & $\begin{array}{l}0,2(1922)+0,3(2299)+0,5(1990)= \\
2069,1\end{array}$ & - \\
\hline Jumlah & & & 576,2 \\
\hline
\end{tabular}

Sumber: Depot AMIU Tirta Asri, 2017.

Menghitung kesalahan atau error dengan menggunakan metode MAD (mean absolute deviation) dan MSE (mean squared error).

Rumus:

$$
\mathrm{MAD}=\frac{\Sigma \mid \text { Aktual }- \text { Peramalan } \mid}{\mathrm{n}}
$$




$$
\begin{gathered}
=\frac{74,7+364,6+136,9}{3} \\
=\frac{576,2}{3}=192,0666 \\
\mathrm{MSE}=\frac{\sum(\text { Kesalahan peramalan })^{2}}{\mathrm{n}} \\
\mathrm{MSE}=\frac{74,7^{2}+364,6^{2}+136,9^{2}}{3}=\frac{5580,09+132933,16+18741,61}{3} \\
=\frac{157254,86}{3}=52418,2866
\end{gathered}
$$

\section{Moving Average}

\begin{tabular}{|c|c|c|c|c|}
\hline Bulan & Periode & $\begin{array}{l}\text { Penjualan } \\
\text { (Yt) }\end{array}$ & $\mathrm{Ft}$ & $\mathrm{Yt}-\mathrm{Ft}$ \\
\hline November & 1 & 2.182 & - & - \\
\hline Desember & 2 & 1.861 & - & - \\
\hline Jamuari & 3 & 2.004 & - & - \\
\hline Februari & 4 & 1.922 & $\begin{array}{l}(2182+1861+2004): 3= \\
2015,6666\end{array}$ & 93,666 \\
\hline Maret & 5 & 2.299 & $(1861+2004+1922): 3=1929$ & 370 \\
\hline April & 6 & 1.990 & $(2004+1922+2299): 3=2075$ & 85 \\
\hline Mei & 7 & - & $\begin{array}{l}(1922+2299+1990): 3 \\
=2070,3333\end{array}$ & - \\
\hline \multicolumn{4}{|l|}{ Jumlah } & $\begin{array}{l}548,66 \\
6\end{array}$ \\
\hline
\end{tabular}

Dalam penelitian ini menggunakan metode moving average dengan $n=3$ (rata-rata tiga bulanan). Rumus:

Tabel 4.4

Hasil Penyelesaian Manual Dengan Metode Moving Average

Sumber: Penulis 2017

Menghitung kesalahan atau error dengan menggunakan metode MAD (mean absolute deviation) dan MSE (mean squared error).

Rumus:

$$
\begin{gathered}
\text { MAD }=\frac{\Sigma \mid \text { Aktual }- \text { Peramalan } \mid}{\mathrm{n}} \\
\mathrm{MAD}=\frac{548,666}{3}=182,8886 \\
\mathrm{MSE}=\frac{\Sigma(\text { Kesalahan Peramalan })^{2}}{\mathrm{n}} \\
\mathrm{MSE}=\frac{93,666^{2}+370^{2}+85^{2}}{=50966,1063}=\frac{8773,319+136900+7225}{3}=\frac{152898,319}{3}
\end{gathered}
$$




\section{Linear Regression}

Tabel 4.5

Hasil Penyelesaian Manual Dengan Metode Linear Regression

\begin{tabular}{|l|l|l|l|l|l|l|}
\hline \multicolumn{1}{|c|}{ Bulan } & $\begin{array}{c}\text { Penjualan } \\
(\mathrm{Yt})\end{array}$ & $\mathrm{X}$ & $(\chi)(\mathrm{y})$ & 2 & $=\alpha+\mathrm{bx}$ & Yt - Ft \\
\hline November & 2.182 & 1 & 2.182 & 1 & 2023,5714 & 158,4286 \\
\hline Desember & 1.861 & 2 & 3.722 & 4 & 2031,3428 & 170,3428 \\
\hline Januari & 2.004 & 3 & 6.012 & 9 & 2039,1142 & 35,1142 \\
\hline Februari & 1.922 & 4 & 7.688 & 16 & 2046,8856 & 124,8856 \\
\hline Maret & 2.299 & 5 & 11.495 & 25 & 2054,657 & 244,343 \\
\hline April & 1.990 & 6 & 11.940 & 36 & 2062,4284 & 72,4284 \\
\hline
\end{tabular}

Sumber: Penulis, 2017

Menghitung kesalahan atau error dengan menggunakan metode $M A D$ (mean absolute deviation) dan MSE (mean squared error).

Rumus:

$$
\begin{aligned}
& \mathrm{MAD}=\frac{\Sigma \mid \text { Aktual }- \text { Peramalan } \mid}{\mathrm{n}} \\
& \frac{158,4286+170,3428+35,1142+124,8856+244,343+72,4284}{6} \\
& =\frac{805,5426}{6}=134,2571 \\
& \mathrm{MSE}=\frac{\Sigma(\text { Kesalahan Peramalan })^{2}}{\mathrm{n}} \\
& =\frac{158,4286^{2}+170,3428^{2}+35,1142^{2}+124,8856^{2}+224,343^{2}+72,4284^{2}}{6} \\
& =\frac{25099,6212+29016,6695+1233,0070+15596,4130+59703,5016+5245,8731}{6} \\
& =\frac{135895,0854}{6}=22649,1809
\end{aligned}
$$

\section{Naive Method}

Teknik forecasting yang mengasumsikan permintaan diperiode mendatang sama dengan peramalan terkini (Deitiana, 2011). Rumus:

Nilai Peramalan 
Tabel 4.6

Hasil Penyelesaian Manual Dengan Metode Naive

\begin{tabular}{|c|c|c|c|c|}
\hline Bulan & Periode & Penjualan (Yt) & $\mathrm{Ft}=\mathrm{Yt}-1$ & $\mathrm{Yt}-\mathrm{Ft}$ \\
\hline November & 1 & 2182 & - & - \\
\hline Desember & 2 & 1861 & 2182 & 321 \\
\hline Januari & 3 & 2004 & 1861 & 143 \\
\hline Februari & 4 & 1922 & 2004 & 82 \\
\hline Maret & 5 & 2299 & 1922 & 377 \\
\hline April & 6 & 1990 & 2299 & 309 \\
\hline Mei & 7 & - & 1990 & - \\
\hline Jumlah & & & & 1232 \\
\hline
\end{tabular}

$$
\begin{aligned}
\mathrm{MAD}=\frac{\Sigma \mid \text { Aktual }- \text { Peramalan } \mid}{\mathrm{n}} & \frac{321+143+82+377=309}{5} \\
\mathrm{MSE}=\frac{\Sigma(\text { Kesalahan Peramalan })^{2}}{\mathrm{n}} & =\frac{321^{2}+143^{2}+82^{2}+377^{2}+309^{2}}{5} \\
& =\frac{103041+20449+6724+142129+95481}{5} \\
& =\frac{367824}{5}=73564,8
\end{aligned}
$$

\subsection{Pembahasan}

Berdasarkan hasil pengolahan data yang telah diteliti dapat dilihat bahwa dari ke enam metode yang digunakan, pemilik depot air minum isi ulang Tirta Asri Tajur Halang dapat menggunakan metode linear regression untuk melakukan peramalan penjualan pada periode-periode berikutnya, karena dari ke enam metode tersebut hasil kesalahan terkecil terdapat pada metode peramalan linear regression.

\section{Simpulan Dan Saran}

\subsection{Simpulan}

Berdasarkan hasil perhitungan dari keenam metode peramalan tersebut, diperoleh hasil peramalan sebagai berikut:

1. Moving Average adalah 2070,3 galon dengan tingkat kesalahan MAD sebesar 182,89 galon dan MSE sebesar 50966, 1 galon. 
2. Weighted Moving Average adalah 2069,1 galon dengan tingkat kesalahan MAD sebesar 192 galon dan MSE sebesar 52418,29 galon.

3. Exponential Smoothing adalah 2069,3 galon dengan tingkat kesalahan MAD sebesar 186,9 galon dan MSE sebesar 44017 galon.

4. Exponential Smoothing With Trend adalah 2023 galon dengan tingkat kesalahan MAD sebesar 177,2 galon dan MSE sebesar 46714,1 galon.

5. Linear Regression adalah 2070,1 galon dengan tingkat kesalahan MAD sebesar 134,2

6. Naive Method adalah 1990 galon dengan tingkat kesalahan MAD sebesar 246,4 galon dan MSE sebesar 73564,8 galon.

Dari keenam metode tersebut, metode yang tepat untuk meramalkan penjualan bulan Mei 2016 yang akan datang pada depot air minum isi ulang Tirta Asri Tajur Halang Bogor adalah metode Linear Regression. Hal tersebut dikarenakan tingkat kesalahan atau MAD pada metode tersebut lebih kecil dibandingkan dengan lima metode lainnya.

\subsection{Saran}

1. Pemilik depot air minum si ulang Tirta Asri Tajur Halang Bogor dapat menggunakan metode Linear Regression untuk meramalkan volume penjualan untuk bulan berikutnya.

2. Diharapkan dengan hasil peramalan penjualan untuk tahun yang akan datang dapat memenuhi kebutuhan masyarakat wilayah Tajur Halang Bogor dan sekitarnya.

\section{Daftar Pustaka}

Boneta, Gisda. 2013. Pengaruh Produk, Harga, Promosi Dan Saluran Distribusi Terhadap Keputusan Pembelian Air Minum Dalam Kemasan Merek Aqua. Skripsi. STIE Bisnis Indonesia. Jakarta.

Deitiana, Tita. 2011. Manajemen Operasi Strategi Dan Analisa. Mitra Wacana Media. Jakarta.

Fahmi, Irham. 2014. Manajemen Keuangan Perusahaan Dan Pasar Modal. Mitra Wacana Media. Jakarta.

Heizer, Jay dan Render, Barry. 2006. Operating Management, Edisi 7. Salemba Empat. Jakarta.

Prihatini, Rohmania. 2012. Kualitas Air Minum Isi Ulang Pada Depot Air Minum Di Wilayah Kabupaten Bogor Tahun 2008-2011. Skripsi Fakultas Kesehatan Masyarakat Program Studi Ilmu Kesehatan Masyarakat Universitas Indonsia. Depok. 20313685-S_Rohmania Prihatini.Pdf.

Sarjono, Haryadi. 2010. Aplikasi Riset Operasi. Salemba Empat. Jakarta.

Sopiah dan Sangadji, Etta Mamang. 2016. Salesmanship. Bumi Aksara. Jakarta.

Suparyanto dan Bari, Abdul. 2014. Pengantar Bisnis. Pustaka Mandiri. Jakarta.

Stepvhanie, Linda. 2012. Peramalan Penjualan Produk Susu Bayi Dengan Metode Grey System Theory Dan Neural Network. Skripsi Fakultas Teknik Program Studi Teknik Industri Universitas Indonesia. Depok. 20310393-S43050-Peramalan Penjualan.Pdf.

Wahyani, Widhy dan Syaichu, Achmad. 2015. Penerapan Metode Peramalan Sebagai Alat Bantu Untuk Menentukan Perencanaan Produksi Di PT Skk. Journal Spektrum Industri. Vol. 13, No. 2, 2015.

Zulkarnain. 2012. Ilmu Menjual Pendekatan Teoritis Dan Kecakapan Menjual. Graha Ilmu. Yogyakarta. 